\title{
Risk Analysis and Efficiency Islamic Banking: Evidence in Indonesia
}

\author{
R. YudhistiraAdi Seputra ${ }^{\mathrm{I}}$, Azhari ${ }^{2}, M D$. Aminul Islam ${ }^{3}$ \\ Universitas Bojonegoro, Indonesia ${ }^{1,2}$, School of Business Innovation \& Techonopreneurship, \\ University Malaysia, Perlis ${ }^{3}$ \\ raden.yudhis@yahoo.co.idt \\ azhari72@yahoo.com² \\ aminsazea@gmail.com ${ }^{3}$
}

\begin{abstract}
$A B S T R A C T$
This study aims to analyze the risk and efficiency of Bank MuamalatTbk, customers \& ex-employees perceptions of the efficiency of the closure of the Branch Offices in Bojonegoro and Blora Regencies. This research is quantitative research that uses three stages of analysis. The first phase of the analysis involves risk analysis by measuring credit, operational and risk of disbursement based on the 2013-20I7 Bank Muamalat Indonesia Tbk Financial Report using CAMELS financial ratios, the second stage consists of measuring the efficiency of Bank MuamalatTbk's performance using non-parametric techniques, Data Envelopment Analysis (DEA). The third stage will apply Pearson Correlation Coefficients to test the correlation between Customer Perception, Credit, Operations, and Risk of Disbursement to Efficiency. Based on results it can be concluded that the condition of Bank Muamalat Indonesia for the period 2013 2017 can be declared unhealthyand risky. So, it is suggested that Muamalat obtain new investors who are able to provide capital to nourish their financial performance.
\end{abstract}

Keywords : Efficiency, Operational Risk, Islamic Banking, Data Envelopment Analysis.

\section{A. INTRODUCTION}

Though Dual Banking System has been implemented based on UU No.23 year I99I, practically both Sharia \& Conventional Banking has still competing sharply. Those banks competition can be seen in a form of Funding Collections and disbursement in a form of loan conducted by Commercial Banks. Practically, many of them are not too careful or even violating the policy of banking principles of prudential banking by giving unlimited loan to a group of clients in that Bank, which may inflict another clients' or bank investors' financial loss, some worse scenario it may give a negative impact on the country's economy, due to Non Performing Finance or Loans. 
In the last five years, NPF/NPL tends to be increased as reported on Annual Financial Reports in several banks both Conventional and Sharia in Indonesia. This NPF is indicated as the trigger of efficiency policy by those bank managements which manifested by closing some of their branch offices in some districts, include the first Sharia Banking in Indonesia, Bank Muamalat Indonesia Tbk.

As another Islamic Banking, PT Bank Muamalat Indonesia offer their services through 270 branch offices, spread all over 33 Provinces in Indonesia, supported by 3.800 Online Post Offices. By Bank of Indonesia's data can be seen the development as presented on table I below.

\section{Table I}

Islamic Banking Network

\begin{tabular}{|c|c|c|c|c|c|c|c|}
\hline Indicator & 2009 & 2010 & 2011 & 2012 & 2013 & 2014 & 2015 \\
\hline Islamic Commercial & & & & & & & \\
\hline $\begin{array}{r}\text { Bank } \\
\text { Number of Banks }\end{array}$ & 6 & II & II & I I & II & $\mathrm{I} 2$ & $\mathrm{I} 2$ \\
\hline Number of Offices & 7II & $\mathrm{I}, 2 \mathrm{I} 5$ & $\mathrm{I}, 40 \mathrm{I}$ & $\mathrm{I}, 745$ & 1,998 & 2,I5I & $2, \mathrm{I} 2 \mathrm{I}$ \\
\hline Islamic Business Unit & & & & & & & \\
\hline $\begin{array}{r}\text { Number of } \\
\text { Conventional Banks }\end{array}$ & 25 & 23 & 24 & 24 & 23 & 22 & 22 \\
\hline that have iB Unit & & & & & & & \\
\hline Number of Offices & 287 & 262 & 336 & 517 & 590 & 320 & 327 \\
\hline Islamic Rural Bank & & & & & & & \\
\hline Number of Banks & $\mathrm{I} 38$ & I50 & I55 & I58 & I63 & 163 & I6I \\
\hline Number of Offices & 225 & 286 & 364 & $40 I$ & 402 & 439 & 433 \\
\hline $\begin{array}{l}\text { Total Number of } \\
\text { Offices }\end{array}$ & 1,223 & $\mathrm{I}, 763$ & $2, \mathrm{IOI}$ & 2,663 & 2,990 & 2,910 & $2,88 \mathrm{I}$ \\
\hline
\end{tabular}

Source: Bank of Indonesia

As seen in table I, the development of Sharia or Islamic Banking tend to be increased from 2010-2013, but then the situation is changed gradually through 20I4-20I7. Some of their Branch offices were closed include Bank Muamalat Indonesia (BMI). Some of them are BMI Branch office Blora and Bojonegoro Regencies where this research is conducted. They were forced to be closed due to many factors, the failure to analyze the risk is suspected to be one of them. Under 
the name of efficiency, BMI Management has to send thousands worker home or took early retirement. It increases the numbers of unemployment in this country. One of the cases which are suspected to be one of the causes of BMI efficiency was Batavia Air Bankruptcy. Metro Batavia was sentenced to experience bankruptcy due to their unpaid loan which was reaching 2,I Trillion Rupiah. As reported by media, Metro Batavia has owned 40 airplanes, and I,4 Billion savings on their Bank. Their loan in BMI reached 428 Billion Rupiah, Bank Capital loan amount 200 Billion Rupiah and Bank Harda amount IOO Billion Rupiah. This is a sample of NPF case experienced by Bank Muamalat Indonesia Tbk.

The NPF issues become a serious problem that burden BMI's steps to move forward. A stated on Media, The Finance and Operational Director of BMI stated that the highest number of NPF contributor in his company are Mining and Transportation sectors, due to unclarity of these two sectors futures. From Transportation sector, the biggest contributor toward NPF case is the bankruptcy of Batavia Airlines. The NPF for this Airline reached I20 Billion Rupiah. At that moment BMI is only hoping by the result of assets auction. For the record, the finance outstanding at that moment was I86 Billion Rupiah. At the end of the year, there was an NPF ratio increase, but it was still 5\%. As the result, Bank Muamalat Indonesia Tbk limited the financing for that both sectors.

Until June 20I5, BUS and UUS assets recorded 272, 39 Trillion or growing about $8,39 \%$ by year to year. On that period, the total of DPK BUS and UUS increased I2, 39\% from I9I, 59 trillion into 20I5, 34 trillion. While the totals of financing disbursement grow 5, 57\% become 203, 89 trillion from I93, I 4 trillion in the same period last year.

That information above indicates Bank Muamalat Indonesia's unhealthiness conditions, which suspected to be one of the platforms for BMI's Management to take an efficiency action. One of the manifestations of their policies is by closing numbers of branch offices, as happened in this research object BMI Branch Offices in Bojonegoro (East Java) and Blora (Central Java) where this research are located as well.

Hussain\& Al - Ajmi (2012)proved that Credit Risk, Liquidity Risk, and Operational Risk are the most important risk that Sharia Banking faced. Supported by data presented on The Table of Bank Muamalat Indonesia's Dynamics of Financial Ratio ROA, CAR, BOPO and NPF 2013 -2016, this research aims to analyze the risk and efficiency of Islamic Banking, specifically Bank Muamalat Indonesia Tbk and the perception of their Customers \&Ex Employees on the efficiency of closing the Branch Office in Bojonegoro and Blora Districts. The Researcher attempts to deepen the analysis \& to gather more 
findings as the evidence to answer the problem formulated under the title The Risk Analysis and Efficiency on Sharia Banking Systems. Case Study: The Closing of Bank Muamalat Indonesia Tbk Branch Offices in Bojonegoro and Blora Regencies. In purpose to answer the problem formulations, the researcher applies three phases of analysis. First is measuring the efficiency of that bank using Data Envelopment Analysis. The next phase is risk analysis by measuring credit, operational and liquidity risks using CAMEL. The third phase uses the Pearson Correlation Coefficient to examine the correlation between Credit Risk, Operations, and Credit Liquidity with efficiency for the 2013-2017 period. This research focuses on risk and how it correlates with efficiency in Islamic Banking, especifically Bank Muamalat Indonesia Tbk as the object of this research. Its important because based on(Nurfalah, I., Rusydiana, A.S., Laila, N., and Cahyono, 2018)Islamic banking industry relatively more stable and resilient compare to conventional banks in the crisis period.

Based on the Research background presented above, there is some problem formulated as mention: (I) Is the customer's credit financing at Bank Muamalat Indonesia Tbk at Risk? (2) Is the operational management Bank Muamalat Indonesia Tbk efficient? (3) How are the perceptions of PT Bank MuamalatBlora and Bojonegoro branches office on the efficiency of the closure of Blora and Bojonegoro Branch offices? This questions will try to be answered.

\section{B. THEORITICAL}

Islamic banking in international terms is known as Islamic banking or better known as interest-free banking. In the operational, Islamic banking face various risk. The risk is the possibility of occurrence of results that deviate from adverse expectations (Sulhan\&Siswanto, 2008: 105). Risk is born because of the uncertainty of the results achieved from a business. Risk management is a set of procedures and methodologies used to identify, measure, monitor, and control risks arising from bank business activities. $\operatorname{In}$ (Shariah Banking Act No 2I, 2008) concerning Islamic banking, the definition of financing is funds agreed between Islamic banks and other parties that require the financed party to return the funds or bills after a certain period with rewards or profit sharing.

Islamic banking have to maintain their efficiency. Gordo (2013) explains that efficiency is the ratio between output and input. This measure refers to technical or operational efficiency (TE) which reflects the company's ability to obtain optimal output from the inputs used, or conversely, the company's ability to utilize at least the inputs to produce a certain number of outputs. The efficiency value is between zero and one. A value of one indicates that the 
company is fully efficient and a value of zero indicates that the company is inefficient.

The "bad luck" hypothesis proposed by Berger \& Young (I997), which is an increase in Non-Performing Loans (NPL) is caused by external factors that cannot be controlled by management such as declining economic conditions. A high NPL can cause banks do not have operational efficiency. In other words, the NPL has an effect on banking technical efficiency.

\section{Preliminary Research}

There are few research have been conducted related to DEA utilization mainly to measure working performance portfolio. Galagedera (2002); McMullen and Strong (I987) conducted one of the research. The research resulted that DEA Model was one of working performance measurement technique alternatives that can be utilized to rank Mutual Fund/Private equities. Muthi et al (I997) also conducted research by analyzing $73 \mathrm{I}$ private equities. In her research, she invented a new measurement called data envelopment portfolio index (DEPI) that similar to Sharpe's index. (Basso, A. \& Funari, S, 200I) conducted the research by applying a model invented by Banker and Morey (I986) and conducted investigations on 50 Private Equities randomly. This research used some input variables, such as subscription cost, redemption cost, and risk.

Surifah (20II) stated that a big company has better sources, lower transaction cost, and has more ability to survive to face the competition and economic crisis. In other word, big companies or a company with big asset tend to be more efficient. Subandi (2014) has also analyzed the factors influencing bank operation's efficiency such as; Total Assets, bank status \& type, CAR Ratio, LDR Ratio, NPL Ratio, Operating expense, and Net Interest Margin (NIM).

Other research using DEA to calculate the productivity and efficiency level of Islamic bank has been done by ( and I. F. Rusydiana, Aam S., 2017) in Indonesian case, (Ascarya \& Yumanita, 2007) with comparation of Indonesia and Malaysian Islamic banks and also (Rani, L., Rusydiana, A., and Widiastuti, 2017) for productivity and efficiency measurement of Indonesia sharia banking.

\section{Hypothesis}

The hypothesis is a summary of the theoretical conclusions obtained from library research. The hypothesis is an answer to a problem that is theoretically considered the most probable and the highest level of truth (Oktavilia, 200I). Starting from the identification of the problem and the framework described earlier, the hypothesis is proposed as follows:

I. Credit financing of customers at Bank Muamalat is at risk

HIo: There is no risk of credit financing at Bank Muamalat

https://ejournal.radenintan.ac.id/index.php/ikonomika

E-mailikonomika_submission@radenintan.ac.id 
HIa: There is a risk of credit financing at Bank Muamalat

2. Operational Management of Bank Muamalat Efficient

HIo: Operational Management of Bank Muamalat is not efficient

HIa: Operational Management of Bank Muamalat Efficient

3. Correlation of risk and efficiency in a Sharia Bank (PT. Bank MuamalatTbk) towards the closing policy of Sub-branch offices in Bojonegoro and Blora Regencies.

HIo: There is no correlation of risk and efficiency in the Sharia Bank (PT. Bank MuamalatTbk) against the closing policy of Sub-branch offices in Bojonegoro and Blora Regencies.

HIa: There is a risk and efficiency correlation in the Sharia Bank (PT. Bank MuamalatTbk) towards the closing policy of Sub-Branch Offices in Bojonegoro Regency and Blora Regency.

\section{METHODOLOGY}

The research was conducted in Bojonegoro (East Java) and Blora (Central Java) Districts in 2017 - 2018. Represented by two Sub-Branch Offices as samples, they were selected by means of Cluster Sampling based on the District. District samples that will be observed are 2 districts in 2 different provinces, Blora Regency is in the Central Java Province and Bojonegoro Regency is in the East Java Province. District determination was carried out purposively based on the district where the closing location of the Branch Office was carried out simultaneously with the conduct of the research.

This research is quantitative research that uses three stepanalysis. The first stage measures the efficiency of Islamic banks using DEA. Second, measure credit, operation and disbursement risk using CAMELS financial ratios. The third stage implements the Pearson Correlation Coefficient to test the correlation between customer assumptions, credit, operational, disbursement risk and efficiency for the 20I3-20I7 period.The data taken from the financial statements of PT. BMI published by Bank Indonesia and OJK. In this study also tested the hypothesis about the effectiveness of the policy of closing the office using the questionnaire with the consumers \& ex-employees of PT. Bank Muamalat Branch Offices Blora\&Bojonegoro as respondents and scale it using a Likert scale.

This study uses a combination of Analytical Survey Methods and Descriptive Survey Methods. Analytical survey method is an investigation method in data collection, where data collected is quantitative data that requires statistical analysis (Yunus, 20I0) so that this method is suitable to answer the first objective of the study. Descriptive survey method is an investigation method in data 
collection, where data collected is qualitative data (Yunus, 2010) so that this method is appropriate to answer and describe the purpose of the second study.

Data collection techniques in this study used the method of observation with non-participation, namely the method of observation where researchers do not involve themselves directly in some customers activities that are not observed fully because of the limited time of researchers (Yunus, 20I0).

In addition, for the objective and valid data to be generated, the researcher will also check information related to the perception of the effectiveness of the office closing policy to customers \& ex-employees. Information gathering is done by interview method with an open list of questions. The qualitative data for deepening analysis was collected through interviews with questionnaires to customers and ex-employees of Muamalat Branch Offices Blora\&Bojonegoro. In addition, for DEA efficiency, input and output variable are also needed \& obtained through the published website of the Financial Services Authority and Bank Indonesia.

The total customer population \& ex-employees of Bank Muamalat Branch Offices Blora\&Bojonegoro amounted to IOO respondents which were presented in table form in the analysis and discussion section. Therefore related to the population, the determination of the population sample in this study uses the snowball sampling technique. According to(Yunus, 20I0), snowball sampling is right for the unknown population size.

\section{Analysis Tools The Camel Ratio Analysis}

In the banking dictionary (Indonesian Banker Institute I999), CAMEL is the aspect which has the most influence on the financial condition of the bank which also affects the healthiness of the bank. CAMEL is a benchmark for the object of bank checks and consist of capital, assets, management, equity and the last liquidity. With ratio analysis can be obtained a picture of the good or bad situation or financial position of a bank. Bank health can be measured by several indicators. One of the main indicators used as a basis for valuation is the bank's financial statements. Based on the financial statements, a number of financial ratios will be calculated as a basis for evaluating the soundness of the bank.Financial ratio analysis allows management to identify key changes in the number trend and the relationship and reasons for the change. The results of the analysis of financial statements will help interpret various relationships and trends that can provide a basis for consideration of the company's potential success in the future. 


\section{Data Envelopment Analysis (DEA)}

DEA method for evaluating the performance of a DMU. Basically, the working principle of the DEA model is to compare the input and output of a data organization (decision making unit, DMU) with other input and output data in a similar DMU. This comparison is done to get a value of efficiency. The DEA model is used as a device to measure performance which has at least 4 advantages over other models. These advantages include:

I. He DEA model can measure many input variables and output variables

2. There is no need to assume functional relationships between the measured variables

3. Input and output can have different measurement units.

The first time the CCR model was discovered by Charnes, Cooper, and Rhodes in 1978 and second the Banker Charnes Cooper (BCC) model. In this model, an efficiency measure for each decision-making unit (DMU) was introduced which is the maximum ratio between weighted output and weighted inputs. Each weight value used in the ratio is determined by the limitation that the same ratio for each DMU must have a value that is less than or equal to one. Thus it will reduce multiple inputs and multiple outputs into one "virtual" input and "virtual" output without requiring the initial determination of the weight value. Therefore the measure of efficiency is a function of the weight value of a combination of virtual inputs and virtual output.

\section{Picture I}

CCR Input and Output Equation Orientation Model

\begin{tabular}{|l|l|}
\hline Output orientation: & Input orientation: \\
Min $\phi_{0}=\sum_{i=1}^{m} v_{i k} x_{i k}$ & $\operatorname{Max} \varphi_{0}=\sum_{r=1}^{t} u_{r k} y_{r k}$ \\
s.t. $\sum_{r=1}^{t} u_{r k} y_{r k}=1$ & s.t. $\sum_{i=1}^{m} v_{i k} x_{i k}=1$ \\
$-\sum_{r=1}^{t} u_{r k} y_{r j}+\sum_{i=1}^{m} v_{i k} x_{i j} \geq 0 \quad(j=1, \ldots, n)$ & $\sum_{r=1}^{t} u_{r k} y_{r j}-\sum_{i=1}^{m} v_{i k} x_{i j} \leq 0 \quad(j=1, \ldots ., n)$ \\
$u_{r k} \geq \varepsilon \quad(r=1, \ldots, t)$ & $u_{r k} \geq \varepsilon \quad(r=1, \ldots ., t)$ \\
$v_{i k} \geq \varepsilon \quad(i=1, \ldots, m)$ & $v_{i k} \geq \varepsilon \quad(i=1, \ldots, m)$ \\
\hline
\end{tabular}

Nowadays, the DEA method is widely applied to measure the technical efficiency of the banking industry (Coelli, T.J, Rao, D.S.P., Prasada Rao, 2005) But now, DEA has also begun to be widely used in measuring the level of efficiency of non-bank institutions, such as hospitals, universities, tax offices, 
including non-profit institutions (Rusydiana, 2013)In Islamic banking, DEA studies has been done by (Nurfalah, I., Rusydiana, A.S., Laila, N., and Cahyono, 2018), (Rani, L., Rusydiana, A., and Widiastuti, 2017),( and Y. D. S. Rusydiana, Aam S., 2018).

\section{Partial Correlation Analysis of Pearson Product Moment}

This partial correlation used to determine the strength of the relationship between the correlations of the two variables where other variables considered influential are controlled or made constant (as a control variable). Because the variables studied are interval data, the statistical technique used is the Pearson Correlation Product Moment (Sugiyono, 2013: 216).According to Sugiyono (2013: 248) the determination of the correlation coefficient using the Pearson Product Moment correlation as follow:

$$
\begin{aligned}
& n \sum x i y i-\left(\sum x i\right)\left(\sum y i\right) \\
& r x y= \\
& \sqrt{ }\left\{n \sum x i 2-\left(\sum x i\right) 2\right\}-\left\{n \sum y i 2-\left(\sum y i\right) 2\right\} \\
& \text { Description: } x y=\text { Pearson correlation coefficient } \\
& x i=\text { independent variable } \\
& y i=\text { Dependent variable } \\
& n=\text { Many samples }
\end{aligned}
$$

From the results obtained by the formula above, it can be seen the level of influence of variables $\mathrm{X}$ and $\mathrm{Y}$. In essence, the value of $\mathrm{r}$ can vary from $-\mathrm{I}$ to $+\mathrm{I}$, or mathematically can be written as $-\mathrm{I} \leq \mathrm{r} \leq+\mathrm{I}$. The results of the calculation will provide three alternatives, namely:

I. If $\mathrm{r}=0$ or close to 0 , then there is no relationship between variable $\mathrm{X}$ to variable $\mathrm{Y}$.

2. If $\mathrm{r}=+\mathrm{I}$ or close to $+\mathrm{I}$, then the correlation between the two variables is strong and unidirectional, said to be positive.

3. If $\mathrm{r}=-\mathrm{I}$ or close to $-\mathrm{I}$, then the correlation between the two variables is strong and opposite direction, said to be negative.

\section{RESULTS AND DISCUSSION}

\section{Non-Performing Finance Sharia Banking}

Non-Performing Financing (NPF) increasingly become burdensome for Bank Muamalat steps. Bank Muamalat, Director of Finance and Operations, revealed that the highest NPF contributor in the company is the mining and transportation sector because the future of the two sectors is blurred. From the transportation sector, one of the debtors who have problems is Batavia Air. The 
bankruptcy case of the Batavia Air airline was the cause. The funding of Bank Muamalat which was caught in the airline was Rp I20 billion. At present Bank Muamalat only hopes for the proceeds of the sale of bankrupt assets.

To find out the description of a relationship or comparison between a certain number and the number of others, researchers used the CAMEL Ratio Analysis. With ratio analysis can be obtained a picture of the good or bad situation or financial position of a bank. Bank health can be assessed from several indicators. One of the main indicators used as a basis for valuation is the bank's financial statements. Based on the financial statements, a number of financial ratios will be calculated to evaluate the health of the bank.

In the banking dictionary (Indonesian Banker Institute I999), CAMEL is the aspect that has the most influence on the financial condition of the bank which also affects the healthiness of the bank. CAMEL is a benchmark for the object of bank checks conducted by bank auditors. Based on data obtained from the Bank of Indonesia, the amount of ROA at Bank Muamalat has fluctuated

Table 2

Financial Ratios of BMI 2013-2017

\begin{tabular}{|c|c|c|c|c|c|c|c|c|}
\hline No & Ratio & 2013 & 2014 & 2015 & 2016 & 2017 & Standards & Notes \\
\hline I & CAR & 17,55 & I4,22 & I2,36 & I2,I & II.58 & $\min 8 \%$ & $\begin{array}{l}\text { Sufficient Capital } \\
\text { Adequacy }\end{array}$ \\
\hline 2 & NPF & 0,78 & 4,76 & 4,2 & 4,33 & 3.07 & $<2 \%$ & $\begin{array}{l}\text { NPF is relatively } \\
\text { High }\end{array}$ \\
\hline 3 & ROA & I,37 & 0,17 & 0,2 & 0,25 & $0 . \mathrm{II}$ & $>1,5 \%$ & $\begin{array}{l}\text { Management } \\
\text { ability to manage } \\
\text { assets is inadequate } \\
\text { to generate profits }\end{array}$ \\
\hline 4 & $\mathrm{z}$ & 85,12 & 97,33 & $97,4 \mathrm{I}$ & 97,32 & 98.I & $\begin{array}{l}60 \%- \\
70 \%\end{array}$ & $\begin{array}{l}\text { Operational costs } \\
\text { are higher than } \\
\text { return }\end{array}$ \\
\hline
\end{tabular}

Based on table II (Dynamics of Financial Ratios ROA, CAR, BOPO, and $\mathrm{NPF}$ ) above, it can be concluded that Bank Muamalat's CAR is still sufficient but has experienced a downward trend from 2013 to December 2017. The biggest decrease was 3.33\% which occurred between 2013 - 20I4. Bank Muamalat's NPF or Non-performing Loans were also considered to be quite high with a percentage of $4.33 \%$ at the end of 2016 amounting to $4.33 \%$ even 
though it decreased at the end of 2017 by $3.07 \%$ but still exceeded the scale of the Bank Indonesia's problematic credit limits maximum 2\%. Management's ability to manage assets to generate profits is also considered to be poor because the percentage has decreased to $0.25 \%$ and continues to decline at the end of 2017 by $0.11 \%$ below the Bank Indonesia quality standard which should be above $1.5 \%$. The latter is a high percentage of OER / BOPO in 2016 of 97, $32 \%$ and continues to increase at the end of 2017 by $98.1 \%$, exceeding Bank Indonesia quality standards, namely the range of $60 \%-70 \%$, which can be assumed that Operational Costs are higher compared to operating income. The high level of non-performing loans, Management's ability to manage assets to produce unfavorable profits, and high operational costs are not offset by this operating income which is alleged to be the background of Bank MuamalatTbk's Management policy to optimize by way of closing sub-branch offices in several areas spread throughout Indonesia. One of them is PT. Bank MuamalatTbk, in Blora Regency \&Bojonegoro Regency which was used as the focus of this research object. The results of data processing Bank MuamalatTbk financial statements can illustrate some of Bank Muamalat's credit liquidity to customers is very risky. Based on the exposure to the CAMEL Ratio Analysis in table II above it can be concluded that the condition of Bank Muamalat Indonesia for the period 2013 - 2017 can be declared unhealthy and risky.

\section{Operational Efficiency of Bank Muamalat}

PT BMI Tbk since a few years ago recorded an unsatisfactory financial performance. Starting from a large NPF, shrinking capital, to a high operating load in accordance with the description described in the Financial Ratio Analysis Table II. The general picture of Bank Muamalat's situation is also reviewed in several media with negative pitches until speculation that they will go bankrupt. Detik Finance released its editorial on February 22, 20I8, at II:I5 a headline "Bank Muamalat Threatened to Bankrupt?"In his review, Detik Finance explained the results of his interview with University of Indonesia (UI) Economic and Business Center Researcher Yusuf Wibisono explaining that the problem faced by Bank Muamalat was due to a problematic financing ratio that was too large. NPF problems are too high."

To test the hypothesis the researcher used DEA to calculate the operational efficiency of Bank Muamalat Indonesia Tbk presented in table III below. 
Table 3

Output DEA BMI Tbk 2013-20I7

\begin{tabular}{|c|c|c|c|c|c|c|c|}
\hline NO & DMU & Score & $\begin{array}{c}\text { Total } \\
\text { Deposits } \\
(\mathrm{XI})\end{array}$ & $\begin{array}{c}\text { Labor } \\
(\mathrm{X} 2)\end{array}$ & $\begin{array}{c}\text { Asset } \\
(\mathrm{X} 3)\end{array}$ & $\begin{array}{c}\text { Financing } \\
(\mathrm{YI})\end{array}$ & $\begin{array}{c}\text { Income } \\
(\mathrm{Y} 2)\end{array}$ \\
\hline I & $\begin{array}{c}20 \mathrm{I} 3- \\
\text { BMI }\end{array}$ & $\mathrm{I}$ & 0 & $\begin{array}{c}-\mathrm{I} .3 \mathrm{E}- \\
06\end{array}$ & 0 & 0 & $\begin{array}{c}3.83 \mathrm{E}- \\
07\end{array}$ \\
\hline 2 & $\begin{array}{c}20 \mathrm{I} 4- \\
\text { BMI }\end{array}$ & $\begin{array}{c}0.9 \mathrm{I} 049 \\
2\end{array}$ & 0 & $\begin{array}{c}-\mathrm{I} .2 \mathrm{E}- \\
06\end{array}$ & 0 & $4 . \mathrm{I} \mathrm{E}-08$ & 0 \\
\hline 3 & $\begin{array}{c}20 \mathrm{I} 5- \\
\text { BMI }\end{array}$ & $\begin{array}{c}0.982 \mathrm{I} 7 \\
5\end{array}$ & 0 & 0 & $\begin{array}{c}-\mathrm{I} .7 \mathrm{E}- \\
08\end{array}$ & $4.47 \mathrm{E}-08$ & $2.5 \mathrm{E}-09$ \\
\hline 4 & $\begin{array}{c}20 \mathrm{I} 6- \\
\text { BMI }\end{array}$ & $\mathrm{I}$ & $\begin{array}{c}-2.6223 \mathrm{E}- \\
08\end{array}$ & $\begin{array}{c}-3.6 \mathrm{E}- \\
07\end{array}$ & 0 & $4.6 \mathrm{E}-08$ & 0 \\
\hline 5 & $\begin{array}{c}20 \mathrm{I}- \\
\text { BMI }\end{array}$ & $\begin{array}{c}0.9 \mathrm{II} 09 \\
8\end{array}$ & 0 & $\begin{array}{c}-\mathrm{I} .2 \mathrm{E}- \\
06\end{array}$ & 0 & $4.42 \mathrm{E}-08$ & 0 \\
\hline
\end{tabular}

Table 3 (DEA BMI Tbk put out 20I3-20I7) above shows the efficiency values of each DMU for 5 years with annual data from 2013 to 2017. From the results of the DEA analysis, it can be seen that DMUs that are perfectly efficient (Constant I00\%) are BMI in 2013 and 2016. In 20I4, 2015 and 2017, there was no efficient DMU. So it can be concluded that BMIs in 2013 and 2016 can relatively maintain their perfect efficient level. Based on the table information, the DMU (Bank) which has the lowest efficiency rate is BMI in 2014 amounting to 91.04\%. This, of course, can be a consideration for DMU who have not been efficient to be able to increase the efficiency. In addition, in general, all DMUs that have not been efficient still reach a high level of efficiency, meaning that they do not reach the lowest level of efficiency above $60 \%$.

Inefficient DMU is divided into two parts, namely Increasing Return to Scale (IRS) and Decreasing Return to Scale (DRS). The DMU is included in the increasing group, namely BMI in 20I4, 2015 and 2017. To reach the level of efficiency, the DMU-DMU can still be improved by looking at the value of its potential improvement. For achieving efficiency, it is important to reduce a lot of costs because the market is saturated, etc.

Referring to DEA Efficiency Analysis data in Table III and CAMEL Ratio Analysis table II above, it can be obtained an illustration that the lowest DMU (Bank) efficiency figures are BMI in 20I4 amounting to 91.04\% and Highest Bank Muamalat NPF Ratio of $4.76 \%$ also happened in the same year. Based on the output of the two data can prove that NPF correlates with Efficiency. This is 
supported by the hypothesis proposed by Berger \& Young. The "bad luck", which is an increase in Non-Performing Loans (NPL), is caused by external factors that cannot be controlled by management such as declining economic conditions. A high NPL can cause banks do not have operational efficiency. In other words, the NPL has an effect on banking technical efficiency.

\section{Customers and Ex-Employees Perceptions of BMI Efficiency}

The performance of Bank Muamalat described in Table 2 and Table 3 it can be proven that there are NPF problems that trigger the efficiency that is exposed in table 3 To get balanced information, the researcher also conducted an interview session with one of Bank Muamalat Indonesia Kudus Branch Officer, Bpk. Budi Raharjo, who is positioned as an Operational Supervisor. The results of interview points are presented below.

Table 4

Interview Results Tabulation

BMI Branch Office Kudus Representative

\begin{tabular}{|c|c|c|}
\hline $\begin{array}{l}N \\
0\end{array}$ & Issues & Interview Results \\
\hline I & $\begin{array}{l}\text { Sharia Bank } \\
\text { Credits }\end{array}$ & $\begin{array}{l}\text { From the BMI perspective, the existence of NPF } \\
\text { confirmation is problematic, but it is also referred to as a } \\
\text { macro-financial crisis or problem on a macro basis. This } \\
\text { was also experienced by all shari'ah and conventional } \\
\text { banking. }\end{array}$ \\
\hline 2 & $\begin{array}{c}\text { Sharia Banking } \\
\text { Operation }\end{array}$ & $\begin{array}{l}\text { Based on the exposure of public media reviews suspect } \\
\text { the existence of NPF problems experienced by Shari'ah } \\
\text { banks which triggered the issuance of the Banking } \\
\text { Operational Efficiency policy with the implementation of } \\
\text { branch office closures. However, this is denied by the } \\
\text { Shari'ah bank by using the term Optimization rather than } \\
\text { Efficiency. So far banking operations are still running } \\
\text { normally. }\end{array}$ \\
\hline 3 & $\begin{array}{c}\text { Sharia Banking } \\
\text { Credit Risk } \\
\text { Liquidity }\end{array}$ & $\begin{array}{l}\text { There is a normative confirmation of the risk of Syari'ah } \\
\text { Bank Credit Disbursement from the perspective of a } \\
\text { Sharia Bank due to risk problems Credit disbursement is } \\
\text { a common problem commonly faced by Islamic banks } \\
\text { and conventional banks. }\end{array}$ \\
\hline
\end{tabular}

https://ejournal.radenintan.ac.id/index.php/ikonomika

E-mailikonomika_submission@radenintan.ac.id 


\begin{tabular}{|c|c|c|c|c|c|c|} 
Customers \&Ex & $\begin{array}{r}\text { Based on the results of literature studies, interviews and } \\
\text { questionnaire results from the customer's perspective } \\
\text { there is a confirmation of the relationship between }\end{array}$ \\
$\begin{array}{c}\text { Perceptions } \\
\text { towards } \\
\text { Efficiency Policy }\end{array}$ & $\begin{array}{r}\text { Islamic Bank Loans, Shari'ah Banking Operations, Risk } \\
\text { of Disbursement of Islamic Bank Loans to Islamic Bank } \\
\text { Efficiency Policies by closing sub-branch offices in } \\
\text { several regions, while the Bank perspective sharia does } \\
\text { not confirm this. }\end{array}$ \\
\hline
\end{tabular}

Based on the interview results tabulation above, it can be concluded that, BMI Tbk did not confirm the significant NPF problems being experienced by Bank Muamalat Indonesia and efficiency policies, as well as the relationship between Sharia Bank Credit, Sharia Banking Operations, Risk of Sharia Bank Credit Disbursement towards Sharia Bank Efficiency Policies by closing subbranch offices in several regions.

To get balanced data, a multivariable analysis was also used to achieve the research objectives, by collecting PT Bank Muamalat's Customer and ExEmployee Perceptions of the Efficiency of Closing the Blora and Bojonegoro Branch Offices. Multivariate analysis was carried out using the analysis of partial correlation used to determine the strength of the relationship between the correlations of the two variables where other variables considered influential were controlled or fixed (as a control variable). (Sugiyono, 2013: 216).

In this study, the number of questionnaires distributed was 100 questionnaires. The questionnaires were distributed to the customers of the Muamalat Sub-Branch bank in Blora Regency and Bojonegoro Regency. From the questionnaires distributed to respondents, IOO were returned to researchers so that the rate of return of the questionnaire (response rate) of this study was 100.0\%. Of all the returned questionnaires, all questionnaires were complete.

The first analysis is conducted by using statistical descriptive analysis. Descriptive statistics are statistics that use numerical and graphical methods to recognize patterns of data, compile information contained in the data, and present the information in the desired form. The use of descriptive analysis has several advantages, namely (Kuncoro, 200I: 30) (I) can present data in the form of tables and graphs; (2) can summarize and explain data in the form of central tendencies and their variations.

Data characteristics for age variables that respondents who have age $<25$ years amounted to 5 people $(5 \%)$ followed by respondents aged $25-<30$ years were 12 people (I2\%). Respondents aged $30-<35$ years and more than 50 years 
each amounted to 8 people (8\%). The number of respondents aged 35- $<40$ years was I5 people (I5\%), respondents aged $40-<45$ years were 45 people $(45 \%)$ and respondents aged $45-<50$ years were 7 people $(7 \%)$. Then it can be seen that the age group of the respondents most in this study was $40-<45$ years old as many as $45 \%$ and followed later respondents aged $35-<40$ years at $15 \%$.

After processing the data, the results of the correlation parameters are obtained as presented in table 5 below :

Table 5

Pearson Correlations Analysis

\begin{tabular}{|c|c|c|c|c|}
\hline & $\begin{array}{l}\text { Consumers } \\
\text { Perceptions }\end{array}$ & $\begin{array}{l}\text { Sharia } \\
\text { Bank } \\
\text { Credits }\end{array}$ & $\begin{array}{c}\text { Sharia } \\
\text { Bank } \\
\text { Operations }\end{array}$ & \begin{tabular}{|c|} 
Credit \\
Risk \\
Liquidity
\end{tabular} \\
\hline $\begin{array}{cr}\text { Consumers } & \begin{array}{r}\text { Pearson } \\
\text { Perceptions } \\
\text { Correlation }\end{array}\end{array}$ & I & $-.25 \mathrm{I}^{*}$ & $.212^{\circ}$ & $-.257^{\text {oit }}$ \\
\hline Sig. (2-tailed) & & .012 & .034 & .010 \\
\hline $\mathrm{N}$ & 100 & 100 & 100 & 100 \\
\hline $\begin{array}{rr}\begin{array}{r}\text { Sharia Banking } \\
\text { Credits }\end{array} & \begin{array}{r}\text { Pearson } \\
\text { Correlation }\end{array}\end{array}$ & $-.25 \mathrm{I}^{*}$ & I & .052 & -.034 \\
\hline Sig. (2-tailed) & .012 & & $.6 \mathrm{II}$ & .735 \\
\hline $\mathrm{N}$ & 100 & I00 & $\mathrm{I} 00$ & 100 \\
\hline $\begin{array}{rr}\text { Sharia Banking } & \begin{array}{r}\text { Pearson } \\
\text { Operations } \\
\text { Correlation }\end{array}\end{array}$ & $.212^{*}$ & .052 & I & $-.197^{*}$ \\
\hline Sig. (2-tailed) & .034 & $.6 \mathrm{II}$ & & .050 \\
\hline $\mathrm{N}$ & $\mathrm{I00}$ & I00 & $\mathrm{I} 00$ & 100 \\
\hline $\begin{array}{rr}\begin{array}{rr}\text { Credit Risk } & \text { Pearson } \\
\text { Liquidity } & \text { Correlation }\end{array}\end{array}$ & $-.257^{+00}$ & -.034 & $-.197^{\circ}$ & I \\
\hline Sig. (2-tailed) & .010 & .735 & .050 & \\
\hline $\mathrm{N}$ & 100 & 100 & 100 & 100 \\
\hline
\end{tabular}

*. Correlation is significant at the 0.05 level (2-tailed).

Correlation is significant at the 0.01 level (2-tailed).

From the output of Table 5 (Pearson Correlation Analysis) above it is known that Customers Perception (Y) with Islamic Bank Credit (XI) has a significance value of $0.012<0.05$ which means there is a significant correlation. Furthermore, Customers Perception (Y) with Sharia Banking Operations (X2) has a significance value of $0.034<0.05$, which means there are a significant 
correlation and Customers Perception (Y) with Credit Disbursement Risk (X3) having a significance value of $0.010<0.05$ which means there is also a significant correlation. So it can be concluded that Customers Perception (Y) with Syari'ah Bank Credit (XI), Shari'ah Banking Operations (X2) and Credit Disbursement Risk (X3) have a significant relationship and among the three variables, Risk Credit Disbursement (X3) has the strongest correlation among the other variables. Based on the above output it is known that the Pearson Correlation value that is connected between each variable has an asterisk which means there is a significant correlation between the variables that are connected.

\section{E. CONCLUSION}

Based on the explanation of the analysis and discussion of the problem formulation the conclusions can be formulated as follows;

Bank Muamalat's CAR is still sufficient but has experienced a downward trend from 2013 to December 2017. The biggest decrease was 3.33\% which occurred between 2013 - 20I4. Bank Muamalat's NPF or Non-performing Loans were also considered to be quite high with a percentage of $4.33 \%$ at the end of 2016 amounting to $4.33 \%$ even though it decreased at the end of 2017 by $3.07 \%$ but still exceeded the scale of the Bank Indonesia's problematic credit limits maximum 2\%. Management's ability to manage assets to generate profits is also considered to be poor because the percentage has decreased to $0.25 \%$ and continues to decline at the end of 2017 by $0.11 \%$ below the Bank Indonesia quality standard which should be above $1.5 \%$. The latter is a high percentage of OER / BOPO in 2016 of $97,32 \%$ and continues to increase at the end of 2017 by $98.1 \%$, exceeding Bank Indonesia quality standards, namely the range of $60 \%$ $-70 \%$, which can be assumed that Operational Costs are higher compared to operating income. The high level of non-performing loans, Management's ability to manage assets to produce unfavorable profits, and high operational costs are not offset by this operating income which is alleged to be the background of Bank MuamalatTbk's Management policy. To optimize by way of closing sub-branch offices in several areas spread throughout Indonesia. One of them is PT. Bank MuamalatTbk, in Blora Regency \&Bojonegoro Regency which was used as the focus of this research object. The results of data processing Bank MuamalatTbk financial statements can illustrate some of Bank Muamalat's credit liquidity to customers is very risky. Based on exposure to the CAMEL Ratio Analysis in table 2 above, it can be concluded that the condition of Bank Muamalat Indonesia for the period 2013 - 2017 can be declared unhealthy and risky. 
From the results of the DEA analysis, it can be seen that DMUs that are perfectly efficient (Constant I00\%) are BMI in 2013 and 20I6. In 20I4, 2015 and 2017, there was no efficient DMU. So it can be concluded that BMIs in 2013 and 2016 can relatively maintain their perfect efficient level. Based on the table information, the DMU (Bank) which has the lowest efficiency rate is BMI in 2014 amounting to $91.04 \%$. This, of course, can be a consideration for DMU who have not been efficient to be able to increase technical efficiency (pure technical efficiency). In addition, in general, all DMUs that have not been efficient still reach a high level of efficiency, meaning that they do not reach the lowest level of efficiency above 60\%. Referring to DEA Efficiency Analysis data in Table 2 and CAMEL Ratio Analysis table 2 above, it can be obtained an illustration that the lowest DMU (Bank) efficiency figures are BMI in 2014 amounting to $91.04 \%$ and Highest Bank Muamalat NPF Ratio of $4.76 \%$ also happened in the same year. Based on the output of the two data can prove that NPF correlates with Efficiency.

From the output of Table 5 (Pearson Correlation Analysis) above, it is known that Customers Perception (Y) with Islamic Bank Credit (XI) has a significance value of $0.012<0.05$ which means there is a significant correlation. Furthermore, Customers Perception (Y) with Sharia Banking Operations (X2) has a significance value of $0.034<0.05$, which means there are a significant correlation and Customers Perception (Y) with Credit Disbursement Risk (X3) having a significance value of $0.010<0.05$ which means there is also a significant correlation. So it can be concluded that Customers Perception (Y) with Syari'ah Bank Credit (XI), Shari'ah Banking Operations (X2) and Credit Disbursement Risk (X3) have a significant relationship and among the three variables, Risk Credit Disbursement (X3) has the strongest correlation among the other variables. Based on the above output it is known that the Pearson Correlation value that is connected between each variable has an asterisk which means there is a significant correlation between the variables that are connected.

Based on data analysis and conclusions above, suggestions can be given as follows. Based on exposure to the CAMEL Ratio Analysis in table 2 above it can be concluded that the condition of Bank Muamalat Indonesia for the period 2013 - 2017 can be declared unhealthy.and risky. Based on this conclusion, it is suggested that Muamalat obtain new investors who are able to provide capital to nourish their financial performance.

Referring to DEA in Table 3 and CAMEL Ratio Analysis table 2 above, it can be obtained an illustration that the lowest DMU (Bank) efficiency figures are BMI in 2014 amounting to $91.04 \%$ and Highest Bank Muamalat NPF Ratio of 
$4.76 \%$ also happened in the same year. Based on the output of the two data can prove that NPF correlates with Efficiency. Based on the conclusion above, it is suggested that the efficiency measures taken by Bank Muamalat Indonesia can continue to be evaluated to reduce the NPF level so that it can maintain the conduciveness of the banking operations of MuamalatTbk.

Based on the conclusion, it is suggested that Bank Muamalat Indonesia Tbk be more transparent towards its customers regarding the problems of optimization or efficiency of their banking operations. Thus, the management of financial institutions must be based on a high sense of trust by their customers. The customer perceives that the condition of the troubled financial performance of Bank Muamalat may worsen. It could influence customers' confidence lackness. It may also trigger the withdrawal of customer funds that can worsen the performance and image of the Sharia banking in general and Bank Muamalat Indonesia Tbk in particular. Bank Muamalat Indonesia is expected to establish communication with customers to ensure that customer funds are guaranteed and secure.

\section{REFERENCES}

Ascarya \& Yumanita, D. (2007). Comparing the Efficiency of Islamic Banks in Malaysia and Indonesia. Paper Presented at IIUM International Conference on Islamic Banking and Finance (IICiBF): Research and Developement between Ideals and Realities. IIUM - Kuala Lumpur, 23-25 April.

Basso, A. \& Funari, S. (200I). A data envelopment analysis approach to measure the mutual fund performance. European Journal of Operation Research, I20(3), 477-492.

Coelli, T.J, Rao, D.S.P., Prasada Rao, C. J. O. and G. E. B. (2005). Introduction to Efficiency and Productivity Analysis, (Second Edition). Kluwer Academic Publishers, Boston.

Nurfalah, I., Rusydiana, A.S., Laila, N., and Cahyono, E. . (2018). Early warning to banking crises in the dual financial system in Indonesia: The markov switching approach. JKAU: Islamic Economics, Vol.3I, No.2, Pp.I33-I56.

Rani, L., Rusydiana, A., and Widiastuti, T. (2017). Comparative analysis of Islamic bank's productivity and conventional bank's in Indonesia period 2008-20I6. In Ist International Conference on Islamic Economics, Business and Philanthropy (ICIEBP 20I7), Pp. II8-I23.

Rusydiana, Aam S., and I. F. (2017). Efficiency versus Maqasid sharia index: An application on Indonesia Islamic bank. Shirkah Journal of Economics and 
Business, Vol 2 No 2, 2017.

Rusydiana, Aam S., and Y. D. S. (2018). Mesuring the performance of Islamic banking in Indonesia: An application of Maslahah efficiency quadrant (MEQ). Journal of Monetary Economics and Finance, Vol 3 Special Issue, Pp.IO3-I3O.

Rusydiana, A. S. dan T. S. C. (2013). Mengukur Tingkat Efisiensi dengan Data Envelopment Analysis. Bogor: SMART Publishing.

Shariah Banking Act No 2I. (2008). Retrieved from https://www.bigo.id/. Yunus, H. S. (2010). Metodologi Penelitian Wilayah Kontemporer. Yogyakarta: Pustaka Pelajar. 
Risk Analysis and Efficiency in Islamic Banking: Evidence in Indonesia

R. YudhistiraAdi Seputra ${ }^{1}$, Azhari' ${ }^{2}$ MD. Aminul Islam ${ }^{3}$

https://ejournal.radenintan.ac.id/index.php/ikonomika 